\title{
PROFIL DISPOSISI MATEMATIS SISWA KEMAMPUAN TINGGI DALAM MENYELESAIKAN SOAL KONTEKSTUAL
}

\author{
Suci Histiyaningsih \\ Prodi Pendidikan matematika, STKIP PGRI Sidoarjo \\ (suciarmandino@gmail.com) \\ Lailatul Mubarokah, Dewi Sukriyah \\ Prodi Pendidikan matematika, STKIP PGRI Sidoarjo
}

\begin{abstract}
ABSTRAK
Tujuan dari penelitian ini adalah untuk mendiskripsikan profil disposisi matematis siswa kemampuan matematis tinggi dalam menyelesaikan soal kontekstual. Penelitian ini merupakan penelitian deskriptif kualitatif. Teknik pengumpulan data dalam penelitian ini adalah tes pemilihan subjek, tes disposisi matematis, wawancara. Hasil Analisis data menunjukkan : subjek dengan kemampuan matematis tinggi dalam menyelesaikan soal kontekstual menunjukkan aspek percaya diri, fleksibel, gigi ulet, dan rasa ingin tahu. Dengan hasil tersebut dapat ditarik suatu pernyataan bahwa disposisi matematis harus senantiasa ditanamkan pada diri siswa dalam setiap pelaksanaan pembelajaran matematika. Selain itu sikap guru dalam pembelajaran matematika harus dapat mencerminkan berbagai karakteristik disposisi matematis untuk dapat diteladani oleh siswa.
\end{abstract}

Kata Kunci : Disposisi Matematis, Soal Kontekstual.

\begin{abstract}
The purpose of this study was to describe the mathematical disposition profile of students with high mathematical abilities in solving contextual problems. This research is a qualitative descriptive study. Data collection techniques in this study were subject selection tests, mathematical disposition tests, interviews. The results of data analysis showed: subjects with high mathematical abilities in solving contextual questions showed aspects of self-confidence, flexibility, resilient teeth, and curiosity. With these results it can be drawn a statement that mathematical dispositions must always be instilled in students in every implementation of mathematics learning. In addition, the teacher's attitude in learning mathematics must be able to reflect the various characteristics of mathematical dispositions to be emulated by students.
\end{abstract}

Keywords : Mathematical Disposition, Contextual Problems. 


\section{PENDAHULUAN}

Sesuai dengan Standart Kompentesi Lulusan Kurikulum 2013, pembelajaran matematika siswa tidak sekedar belajar pengetahuan, namun diharapkan memiliki sikap kritis dan cermat, obyektif dan terbuka, menghargai keindahan matematika, rasa ingin tahu, berfikir dan bertindak kreatif, serta senang belajar matematika. Sikap dan kebiasaan berfikir seperti ini pada hakekatnya akan menumbuhkan disposisi matematis. Disposisi matematis berkaitan dengan bagaimana siswa memandang dan menyelesaikan masalah; apakah siswa percaya diri, tekun, berminat dan berfikir terbuka untuk mengeksplorasikan berbagai alternatif strategi penyelesaian masalah.

\footnotetext{
Disposisi matematis siswa dikatakan baik jika siswa tersebut menyukai masalah-masalah yang merupakan tantangan serta terlibat secara langsung dalam menyelesaikan masalah (Nopriana, 2015). Salah satu contoh tantangan dapat berupa soal kontekstual. Soal Kontekstual matematika merupakan soal-soal matematika yang menggunakan berbagai konteks situasi yang pernah dialami secara real bagi siswa.
}

Abidin (1989) mengemukakan bahwa soal kontekstual adalah soal yang disajikan dalam bentuk cerita pendek. Pada soal kontekstual matematika konteks yang digunakan dapat menghadirkan situasi yang pernah dialami secara real bagi siswa yaitu berupa masalah kehidupan seharihari.

Profil disposisi matematis siswa dalam penelitian ini adalah gambaran atau deskripsi tentang kecenderungan siswa untuk bersikap posistif dalam pembelajaran matematika dengan mengekplorasikan sebagai alternatif penyelesaian matematika. Disposisi matematis siswa dikatakan baik jika siswa tersebut menyukai masalah-masalah yang merupakan tantangan serta melibatkan dirinya secara langsung dalam menemukan atau menyelesaikan masalah.

Pada penelitian Mahmudi pada tahun 2010 pada suatu SMP di Yogyakarta menunjukkan bahwa siswa yang memiliki tingkat disposisi yang tinggi cenderung memiliki kemampuan matematis yang tinggi dibandingkan dengan siswa yang memiliki tingkat disposisi matematis yang rendah. Untuk itu peneliti tertarik melakukan penelitian yang sama dengan 
subjek yang berbeda yaitu terkait disposisi matematis

\section{METODE}

Penelitian ini merupakan penelitian deskriptif kualitatif, yang bertujuan untuk mendeskripsikan profil disposisi matematis siswa dalam menyelesaikan soal kontekstual. Data yang diperoleh pada penelitian ini berupa tes disposisi matematis dan wawancara. Teknik yang digunakan pada penelitian ini adalah Rich and thick description. Pada penelitian ini subjek yang digunakan adalah siswa kelas VIII yang bertempat tinggal disekitar lingkungan peneliti. Pemilihan subjek dalam penelitian ini dengan cara pemberian tes soal pemilihan subjek. Selanjutnya pemilihan subjek penelitian berdasarkan tingkat kemampuan matematika siswa dalam menyelesaikan tes pemilihan subjek. Dirjen Dikti (2010) menyatakan bahwa dalam menetapkan kriteria kemampuan matematis tinggi yang harus dicapai adalah $\geq 70 \%$.

Setelah subjek penelitian terpilih dilakukan tes diposisi matematis siswa untuk mengukur diposisi matematis subjek terpilih. Lembar tes berupa soal kontekstual, dimana soal yang diberikan soal uraian. Tes disposisi matematis ini diberikan untuk mengklarifikasikan kualitas jawaban siswa yang berkemampuan matematis tinggi dalam menyelesaikan soal kontekstual matematika, untuk membantu mengukur disposisi matematis yang mencakup deskripsi indikator disposisi matematis. Wawancara dilakukan pada tahap terakhir yaitu setelah siswa yang kemampuan matematis tinggi selesai pada tahap tes disposisi matematis dengan memberikan pertanyaan-pertanyaan yang sesuai dengan indikator disposisi matematis dalam menyelesaikan soal kontekstual. Mendiskripsikan bagaimana kemampuan representasi subjek DN siswa yang berkemampuan matematis tinggi,

Tahap terakhir yaitu tahap wawancara yang pelaksanaannya dilakukan setelah subjek menyelesaikan tes soal disposisi matematis. Tahap wawancara dilakukan untuk memberikan penjelasan lebih lanjut dari hasil pekerjaan subjek dalam menyelesaikan soal tes disposisi matematis untuk mengukur aspek-aspek percaya diri, rasa ingin tahu, fleksibel, gigih dan ulet.

\section{HASIL PENELITIAN DAN} PEMBAHASAN

Hasil Analisis Tes Disposisi Matematis Subjek DN (Kemampuan Matematis Tinggi) 


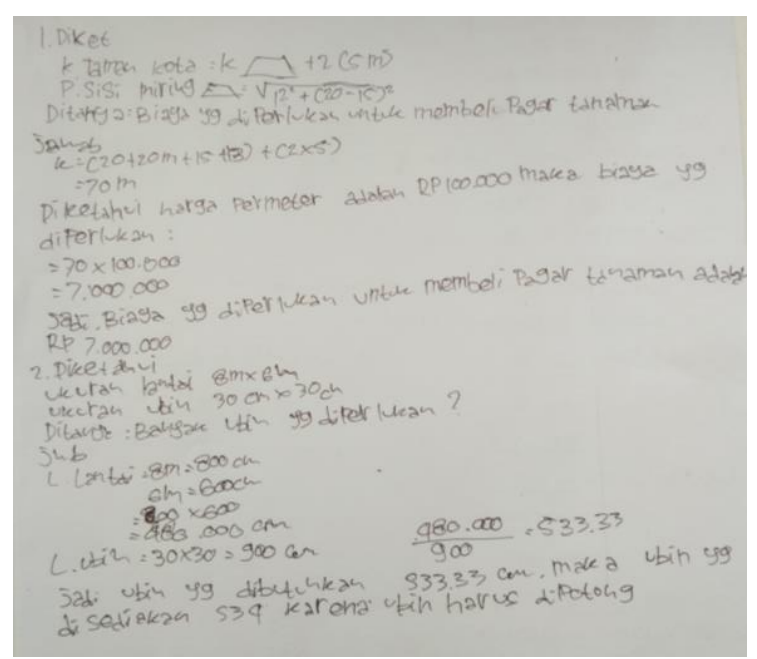

Gambar 4.1 Penyelesaian subjek DN pada soal nomor $1 \& 2$

Pada jawaban soal nomor 1 indikator yang muncul pada subjek DN adalah rasa ingin tahu. subjek DN mampu menentukan ukuran dan biaya yang dibutuhkan dengan hasil penyelesaiannya benar. Pada soal nomor 2 subjek DN mampu menentukan ukuran dan kebutuhan dengan penyelesaian yang benar, meskipun proses penyelesaiannya panjang, subjek masih berusaha menyelesaikan sampai memperoleh jawaban.

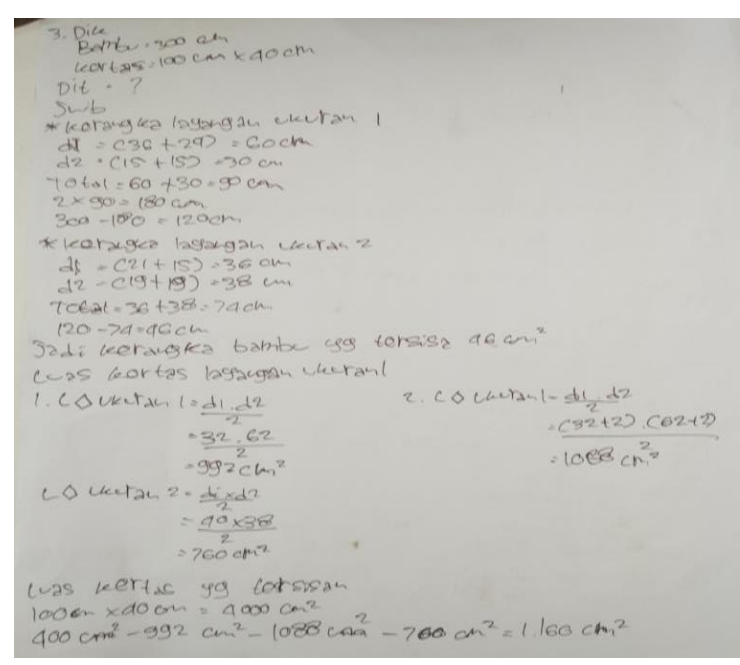

Gambar 4.2 Penyelesaian subjek DN pada soal nomor 3 poin a

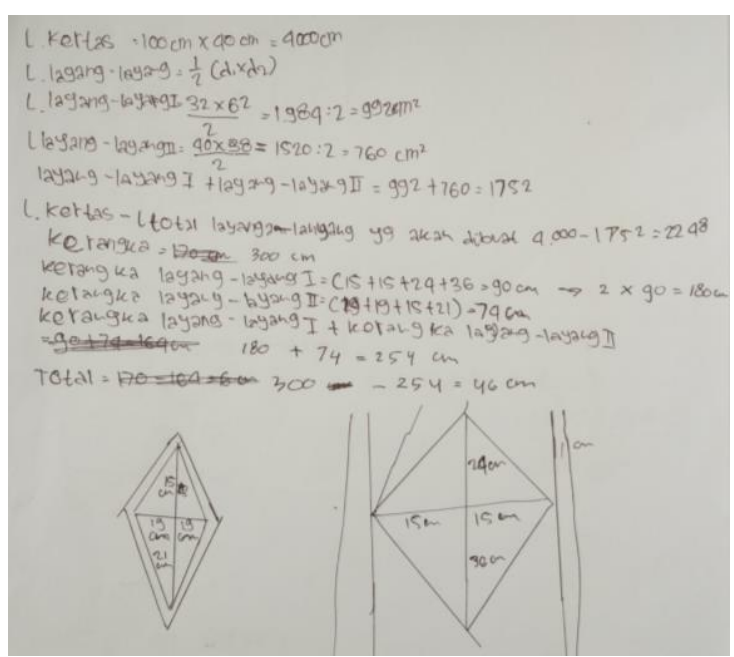

Gambar 4.3 Alternatif penyelesaian subjek DN pada soal nomor 3 poin $b$

Pada jawaban soal nomor 3 indikator yang muncul pada subjek DN adalah gigih dan ulet. subjek DN mampu menentukan ukuran dan kebutuhan serta, mampu membuat sketsa pada soal nomor 3 dengan benar. Subjek DN mampu menyelesaikan semua soal yang disajikan dengan benar. Subjek DN dapat menyelesaikan soal dengan alternatif penyelesaian lain pada soal nomor 3 meskipun proses penyelesaiannya panjang, subjek masih berusaha menyelesaikan sampai memperoleh jawaban dengan benar.

Hasil wawancara yang telah diperoleh dari setiap subjek dalam menyelesaikan soal Tes Disposisi Matematis, kemudian ditranskipkan dan di sajikan. Hasil wawancara ditranskipkan dan disajikan untuk mengetahui disposisi matematis siswa.

PDN01 : "Saya lihat dari hasil pekerjaan kamu, kamu mampu 
menyelesaikan semua soal. Apakah kamu memahami semua soal ini?"

SDN01 : "Iya, saya memahami soal ini"

PDN02 : “Apa yang kamu lakukan ketika mengalami kesulitan dalam mengerjakan soal matematika?"

SDNO2 : "Iya, saya baca-baca lagi soalnya lalu mencari dan menghitung jawabannya."

PDN03 : "Terus bagaimana?"

SDN03 : "Iya begitu saja sampai ketemu hasilnya"

PDN04 : "Apakah kamu percaya diri ketika mengerjakan soal matematika?"

SDN04 : "Iya,saya yakin penyelesaiannya sudah benar"

Berdasarkan transkip wawancara subjek DN pada indikator disposisi matematis aspek percaya diri di atas. Subjek DN memahami semua soal (SDN01). Subjek DN mengerti maksud dari soal, jika mengalami kesulitan subjek mengulang membaca soal (SDN02). Subjek DN memiliki rasa optimis, tidak ragu-ragu untuk menyelesaikan soal (SDN04).

Berikut kutipan wawancara subjek DN (Kemampuan Matematis Tinggi) pada indikator disposisi matematis aspek Fleksibel :
PDN05 : "Trus ketika menyelesaikan soal matematika, apakah kamu mencari sumber lain untuk mengerjakannya?"

SDN05 : "Iya, agar lebih muda untuk menentukan jawabannya"

PDN06 : "Apakah kamu mampu menyelesaikan soal no.3 dengan alternatif penyelesaian lain?"

SDN06 : "Iya, saya selesaikan dengan dua alternatif"

Berdasarkan transkip wawancara subjek DN pada indikator disposisi matematis aspek Fleksibel. Subjek DN dalam menyelesaikan soal matematika mencari sumber lain (SDN05). Subjek DN dapat menyelesaikan soal dengan alternatif penyelesaian lain (SDN06).

Berikut kutipan wawancara subjek DN (Kemampuan Matematis Tinggi) pada indikator disposisi matematis aspek Gigih dan Ulet :

PDN07 : "Jika ada soal yang menurut kamu sulit, apa kamu akan tetap menyelesaikan soal dengan cara lain atau tidak anda hiraukan?"

SDN07 : "Iya, saya mengerjakan yang mudah dahulu, yang susah saya terakhirkan biar tidak menghabiskan waktu"

PDN08 : "oww, trus apa ada hal yang mengganggu kamu pada saat menyelesaikan soal?" 
SDN08 : "Tidak."

PDN09 : "Beneran?"

SDN09 : "Iya"

Berdasarkan transkip wawancara subjek DN pada indikator disposisi matematis aspek gigih dan ulet diatas. Subjek DN tidak pantang menyerah untuk mencari alternatif yang berbeda untuk menyelesaikan soal sulit" (SDN07).

Subjek DN tekun dalam menyelesaikan soal atau tidak mudah terkecoh oleh halhal yang mengganggu (SDN09).

Berikut kutipan wawancara subjek DN (Kemampuan Matematis Tinggi) pada indikator disposisi matematis aspek Rasa Ingin Tahu :

$$
\begin{aligned}
& \text { PDN10: “Apakah kamu mencoba } \\
& \text { mencari jawaban dari soal } \\
& \text { dengan menggunakan alternatif } \\
& \text { berbeda?" } \\
& \text { SDN10:"'Iya, } \quad \text { saya mencoba } \\
& \text { menyelesaikan dengan cara yang } \\
& \text { sudah saya ketahui, ada juga } \\
& \text { yang dari guru matematika dan }
\end{aligned}
$$

ada yang menurut saya benar saya coba."

PDN11 :"Dinomor berapa?"

SDN11 :"nomor 3a"

PDN12 :"oke, kita lanjut dengan pertanyaan terakhir, apakah kamu bertanya pada orang lain ketika menyelesaikan soal matematika?"

SDN12 :"Tidak".

Berdasarkan transkip wawancara subjek DN pada indikator disposisi matematis aspek rasa ingin tahu diatas, subjek DN sudah mencoba jawaban semua soal dengan memakai cara yang berbeda dari yang diberikan, yaitu dengan memakai cara yang dia ketahui sendiri dan juga da yang dari guru matematikanya" (SDN10). Subjek DN mampu menyelesaikan soal tanpa bertanya kepada orang lain (SDN12).

\section{Data Rich and thick Subjek DN}

(Level Kemampuan Matematis Tinggi)

\begin{tabular}{cll}
\hline Indikator & \multicolumn{1}{c}{ Teknik } & \multicolumn{1}{c}{ Hasil } \\
\hline Wercaya Diri & Wawancara & $\begin{array}{l}\text { Subjek DN memahami semua soal, } \\
\text { subjek DN juga mengerti maksud } \\
\text { soal dan tidak mengalami kesulitan, } \\
\text { optimis dan tidak ragu-ragu }\end{array}$
\end{tabular}


Tes Disposisi Matematis

Fleksibel

Wawancara

Gigih dan ulet

Tes Disposisi Matematis

Wawancara

Wawancara

Rasa ingin

tahu
Subjek DN mampu menyelesaikan soal nomor 3 dengan lebih dari satu cara penyelesain dengan menggunakan rumus yang tepat dalam menyelesaikan soal.

Subjek DN dalam menyelesaikan soal mencari sumber lain, subjek DN juga membaca berulang kali untuk memahami soal dalam menyelesaikan soal subjek DN mampu memberikan alternatif lain.

Subjek DN mampu menyelesaikan semua level soal, baik itu soal sulit maupun soal mudah

Subjek DN tidak pantang menyerah untuk mencari alternatif lain serta tidak mudah terkecoh.

Subjek DN menjawab soal dengan cara yang diketahui saja dan subjek DN juga mampu menyelesaikan soal.
Dari penyajian tabel maka subjek DN pada kemampuan matematis tinggi mampu atau banyak memunculkan aspekaspek percaya diri, fleksibel, gigih ulet, dan rasa ingin tahu yang sesuai dengan sub indikator disposisi matematis yang menjadi fokus pada penelitian ini dalam menyelesaikan soal kontekstual.

Berdasarkan hasil penelitian bahwa disposisi matematis subjek kemampuan tinggi banyak memunculkan aspek-aspek percaya diri, fleksibel, gigih ulet, dan rasa ingin tahu yang sesuai dengan sub indikator disposisi matematis. Hal ini sejalan dengan penelitian oleh Trisnowali (2015) yang menyatakan bahwa hasil disposisi matematis siswa kemampuan tinggi mampu memunculkan aspek percaya diri dalam menyelesaikan masalah, fleksibel dalam mengeksplorasikan ide-ide matematika, gigih ulet dalam menyelesaikan soal matematika serta tidak mudah putus asa, rasa ingin tahu dalam akan mengakibatkan seseorang terus belajar sehingga terus berupaya menggalih informasi-informasi terkait.

\section{SIMPULAN}


Histiyaningsih, Profil Disposisi ...

Berdasarkan hasil pembahasa maka

profil disposisi matematis siswa dalam menyelesaikan soal kontekstual pada siswa kelas VIII dapat disimpulkan bahwa Disposisi matematis siswa dengan kemampuan matematis tinggi dalam menyelesaikan soal kontekstual menunjukkan aspek percaya diri, fleksibel, gigi ulet, dan rasa ingin tahu yang positif.

Adapun saran yang perlu disampaikan oleh peneliti berdasarkan penelitian yang telah dilakukan adalah: (1) sebaiknya dalam mengelompokkan tingkat kemampuan matematis siswa yang diambil tidak hanya dari satu materi sehingga pengelompokan kemampuan matematis tingkat tinggi cukup akurat, (2) sebaiknya pada proses wawancara digali lebih dalam bagaimana kemampuan siswa. 


\section{DAFTAR PUSTAKA}

Abidin, (1989). "Study Tentang Prestasi Siswa di Kodya Banda Banda Aceh dalam Menyelesaikan Soal Hitungan dan Soal Cerita". Tesis. Malang : PPs IKIP Malang.

Andani, M. (2016).Deskripsi Disposisi Matematis Siswa dalam Pembelajaran Socrates kontekstual. Lampung : Universitas Lampung.

Cholik, A. (2003). Matematika untuk SLTP kelas 2 Semester 2, (Jakarta : Penerbit Airlangga) 2003, hal. 38.

Fadila, R. (2016). Profil Respon Siswa Terhadap Soal Matematika Berdasarkan Soal Kontekstual. Surabaya : Unesa.

Karlimah. (2010). Mengembangkan Kemapuan Komunikasi dan Pemecahan Masalah serta Disposisi Matematis Mahasiswa PGSD Melalui Pembelajaran Berbasis Masalah. Disertasi pada Universitas Pendidikan Indonesia. Bandung : Tidak diterbitkan.

Kartz, L.G. (2009). Disposition as Educational Goals. [Online] tersedia pada

www.edpsycinteractive.org/file s/edoutcomes.html.Diunduh tanggal 26 Oktober 2019.
Mahmudi, A. (2010). Tinjauan Asosiasi antara Kemampuan Pemecahan Masalah Matematis dan Disposisi Matematis. Makalah Seminar Nasional Pendidikan Matematika(pp. 1-11) Yogyakarta : UNY.

Maxweel. (2001). "Positif learning disposition in mathematics". [Online] Tersedia di : http://www.education.auckland .ac.nz/uoa/fms/default/educatio n/docs/word/research/foed_pap er/issue11/ACE_Paper_3_Issue _11.doc Diunduh tanggal 26 Oktober 2019.

Moleong, L.J. (2014). Metodologi Penelitian Kualitatif (edisi revisi).Bandung : Rosdakarya.

Nasution, E.Y.P (2016). Analisis terhadap Disposisi Matematis Siswa SMK pada Pembelajaran Matematika. Logaritma, Vol 4(1), 77-95.

NCTM. (1989). Curucukum and Evaluation Standard for School Mathematics. Virginia : The NCTM Inc. [Online]. Tersedia : http://www.nctm.org/focalpoint s. Diunduh tanggal 26 Oktober 2019.

Nopriana, T. (2015). Disposisi Matematis Siswa Melalui Model Pembelajaran Geometri Van Hiele. Jurnal Pendidikan Matematika \& Matematika, vol 1(2), 80-94. 
Parno. (2014). Profil Kemampuan Siswa dalam Menyelesaikan Soal Matematika Bilangan Bulat Berdasarkan Keaktifan Bertanya dalam Proses Belajar Kelas VII SMPN 1 Candi Tahun Pelajaran 2014/2015. Sidoarjo : STKIP PGRI.

Polking, J. (1998). Respon To NCTM's Roun 4 Question. [Online] tersedia pada http://www.ams.org/governmen t/argrpt 4.html. Diunduh tanggal 26 Oktober 2019.

Sitorus, R. (2006). Bimbingan Pemantapan Matematika SMP, (Bandung: CV. Yrama Widya), 2006, hlm.41.

Sumarno, U. (2012). Pendidikan Karakter serta Pengembangan Berfikir dan Disposisi Matematik dalam Pembelajaran Matematika. Makalah Seminar Pendidikan Matematika. NTT : UPI.

Syaban, $\quad$ M. (2009). Menumbuhkembangkan Daya dan Disposisi Matematis Siswa Sekolah Menengah Atas Melalui Pembelajaran Investigasi. Jurnal Educationist, vol 3(2), 129136.

Sormin. (2017). Peningkatan Kemampuan Komunikasi dan Disposisi Matematis Siswa Melalui Pembelajaran Koperatif tipe jigsaw. Di Smp Muhammadiyah Kota Padangsidimpuan. Jurnal PARADIKMA. 10(2) :halaman 165-180.
Trisnowali, A. (2015). Profil Disposisi Matematis Siswa Pemenang Olimpiade pada tingkat Provinsi Sulawesi Selatan. Journal of East, vol 1(3), hal 47-57.

Zulkardi, \& Ilma, R. (2006). Mendesain Sendiri Soal Kontekstual Matematika. Prosiding KNM 13 Semarang (pp. 1-6). Palembang : Unsri. 
Jurnal Edukasi, Volume 6 No.2, Oktober 2020

EISSN. 2598-4187 ISSN. 2443-0455 